\title{
ІНТЕРПРЕТАЦІЯ ОРІСНТАЛЬНОЇ МОДЕЛІ ІНТЕЛЕКТУАЛЬНОГО КОНСТРУЮВАННЯ СВІТУ У ДРАМАТИЧНИХ ПОЕМАХ ЛЕСІ УКРАЇНКИ
}

Агібалова Т. М. Інтерпретація орієнтальної моделі інтелектуального конструювання світу у драматичних поемах Лесі Українки.

У статті досліджено специфіку вербалізації єгипетського культурного простору в концептуальній картині світу Лесі Українки. Проаналізовано лінгво-естетичні домінанти, що формують інтелектуальний базис драматичної творчості письменниці.

Ключові слова: орієнтальний текст, інтелектуалізація літературної мови, вербалізація, культурний простір, лінгво-естетичний знак культури, концептуальна картина світу.

Агибалова Т. Н. Интерпретация ориентальной модели интеллектуального конструирования мира в драматических поэмах Леси Украинки.

В статье рассматривается специфика вербализации египетского культурного пространства в концептуальной картине мира Леси Украинки. Анализируются лингво-эстетические доминанты, формирующие интеллектуальный базис драматического творчества писательницы.

Ключевые слова: ориентальный текст, интеллектуализация литературного языка, вербализация, культурное пространство, лингво-эстетический знак культуры, концептуальная картина мира.

Agibalova T. N. The interpretation of oriental model of the world's intellectual construction in Lesya Ukrayinka's dramatic poems.

The article deals with the specificity of representation of The Egyptian Cultural Space in Lesya Ukrayinka's dramaturgic heritage. The linguo-aesthetic dominants that form an intellectual basis of authoress`s literary works are analyzed.

Key words: oriental text, intellectualization of the literary language, verbalization, cultural space, linguo-aesthetical sign of culture, conceptual picture of the world.

На сучасному етапі розвитку когнітивної лінгвістики й лінгвокультурології мова розглядається як інтелектуальне надбання, естетичний вимір національної ментальності. Принцип дослідження мовних явищ як культурних феноменів зумовив зростання інтересу науковців до вивчення процесів інтелектуалізації літературної мови, об'єктивованої в персоніфікованому слові, - у зв'язку 3 концептуальною картиною світу митця. У центрі уваги лінгвістичного дискурсу початку століття знаходяться не окремі фрагменти 
мовленнєвої діяльності, а генезис мовомислення знакових постатей епохи як інтерпретація моделі інтелектуального конструювання світу (С. Срмоленко, Л. Шевченко, Л. Мацько, Л. Ставицька, Л. Лисиченко, О. Маленко, К. Голобородько, В. Калашник, О. Тараненко та ін.).

Письменницька мовотворчість осмислює, вербально естетизує парадигматику всесвіту. Досвід, знання, культурна пам'ять етносу $є$ «своєрідною формулою володіння світом, якою користується митець, розвиває іi, наповнює новою культурологічною сутністю» [4]. Світогляд, психотип автора визначають предмет зображення й відповідно до цього коло номінацій, їхнє семантичне наповнення. Л. Лисиченко наголошує, що мова художнього твору як інтелектуалізована діяльність $є$ наслідком не штучного «надумування», а глибинних процесів селекції мовного матеріалу, яка залежить від внутрішнього світу письменника, зумовленого культурно-історичними, соціальними факторами, психічними основами особистості [1, с. 168].

У такому аспекті актуальним $є$ дослідження специфіки лінгвалізації культурної пам’яті людства, закладеної в інтелектуальні парадигми Давнього Сходу в ідіолекті Лесі Українки, адже мовні пошуки поетеси координують із мовно-літературними процесами кінця XIX - початку XX століття на шляху до інтелектуалізації мови художньої літератури, до збагачення iї здобутками світової культури й науки. Утілюючи парадигматику естетизованого осягнення буття, Леся Українка створювала нові яскраві смисли, розширювала обрії національного художнього слова. Мовно-естетичні здобутки авторки полягають у залученні до національного мовного континууму значних культурно-історичних шарів лексики, пов'язаних із староєгипетськими темами, що сприяло розширенню лексико-семантичної системи української мови. Творчий потенціал письменниці «виростає» із серцевини своєї культури, але у процесі її переосмислення, тому Леся Українка постає перед нами не просто нащадком культурних здобутків попередніх поколінь, а їх генератором. Мета дослідження - виявити специфіку мовної репрезентації орієнтальної моделі буття у драматичній поемі «В дому роботи, в країні неволі», що об'єктивує коло етичних та історико-філософських інтересів авторки: культура давніх цивілізацій, тема неволі, моральний вимір особистості.

Орієнтальний текст письменниці не є знаковим у тому сенсі, що фіксує на папері факти й події, він «загартований» палкою жагою до пізнання, «інкрустований» винятковою науковою ерудицією та 
естетикою емоційної напруги. Дійсно, він $є$ знаковим, але цей знак епохальної значущості вміщує в собі інтелектуальну метафору всесвітнього універсуму, космогонічний міф, культурний код. У вступі до підручника «Стародавня історія східних народів» письменниця декларує свою пошукову мистецьку концепцію, вказуючи на те, що саме «з останків давнього хисту, ми бачимо правдиву, певну історію, історію хисту, історію циивілізацї̈».

Для Лесі Єгипет означав полегшення хвороби, позитивні конотації, пов'язані з перебуванням у східному Гелуані, постійно звучать у листах до рідних і друзів: «Як я щее на морі, наближаючись до Єгипту, побачила яскраве сонце $і$ ясне небо і почула тепло, то готова була «в личях» зобразити «die Freundre der Natur». Tym тепер тепло і ясно, але кажуть, щзо се недавно, а то й був дощ $і$ холод (ет, щзо вони тут знають про холод!). Либонь, мине ще кілька днів, поки я зможу як слід писати» (3, т. 12, с. 334); «Може Сzипет нагородить мене за всі подорожні $i$ передвиїзні тарапати» (3, т. 12, с. 333); «... може, я відігріюся $і$ прийду в людський стан» (3, т. 12, с. 335); «Вага збільшується, темп[ература] унормувалась, аналіз показує навіть поліпшення проти торішнього» (3, т. 12, с. 335-336). Але не тільки порятунку від болю фізичного шукала поетеса в казковій країні фараонів. Дивовижний східний світ із його напрочуд екзотичною міфологією, мовою, історією, культурою, що в його долині повноводного Нілу зародилась одна 3 найдавніших i найрозвиненіших цивілізацій в історії людства, причарував Лесю Українку. Ніл як «колиска всесвіту», Сфінкс, що у свідомості поетеси викликав асоціації з Утаємниченим, Сонцем, Правдою, Долею, Життям, Коханням: Там списані були усі імення / Тої потвори: Сонце, Правда, Доля, / Життя, Кохання і багато інших. / Та краще всіх пристало слово: Сфінкс - / Воно таємне, як сама потвора (3, т. 10, с. 205).

Подорожі до Єгипту, засвоєння естетики його природи та культури надихнули Лесю Українку на створення нових унікальних лінгвопросторів, зумовлених глибиною іiі історіософського бачення світу. Шари лексики на позначення єгипетського хронотопа декодифікують для української ментальності мови давніх високорозвинений цивілізацій, привносять у сучасний письменниці мовний континуум факти та ідеї, пов'язані з культурним життям цих країн, знайомлять українців як $з$ архітектонікою філософсько-релігійної думки, так і з соціально-політичним становищем давніх цивілізацій, збагачують національний лексикон словами, що мають значне історіо- 
й культурософське смислове навантаження. У цьому полягає роль письменниці в інтелектуалізації української літературної мови.

Так, у драматичній поемі «В дому роботи, в країні неволі» мовне вираження образу Сгипту виформовується низкою лексичних одиниць на позначення екзотичного східного простору, орнаментованих «єгипетським настроєм»: літо, гаряче сонце, спека, полуднева змора, сухе марево, розпечений пісок, пальми, гаряче каміння, раби, пустеля, Ніл, мул, піраміди, саркофаги, храми, статуї фараонів, зарослі nапірусу та лотосу, глиняні тиковки для питної води тощо. Інтелектуалізацію української літературної мови забезпечило широке використання Лесею Українкою онімів, що ідентифікують міфічних персонажів єгипетської культури й репрезентують авторський спосіб інтелектуального освоєння світу в усіх його вимірах, зокрема 3 огляду на персоналії, матеріальні й духовні цінності людства: Рa, Горус, Озіріс, Ізіда, Фта, Тот, Нейт, Аммон, Апіс, Анубіс.

Лінгвальний простір орієнтального тексту має дихотомічний характер і виформовується в такий спосіб, що художньо-семантичну площину драматичної поеми розділено на дві напівплощини: 1. Оспіваний у ліричних творах Сгипет золотавий - екзотична країна Давнього Сходу, що їі ототожнено із сонцем золотим, гарячим піском, величчю богів, казкової краси Нілом. 2. Сгипет - «країна неволі», що уособлює інший світ, який вимагає людських страждань, сліз і тяжкої праці аж до кривавого поту.

Художньо-семантичну напівплощину Сгипет золотавий, репрезентовану мовною свідомістю та почуттєвими враженнями авторки, подано в двох основних вимірах. Перший - це східна країна, що має такі характеристики: 1) відповідне географічне розташування, ландшафтні та кліматичні характеристики: залита сонячним світлом полудневим, площуа в околичі Мемфіса (2, с. 242); на заході вона переходить у справжню пустелю, піскувату, повиту сухим маревом (2, с. 242); маревом, тремтячим від спеки (2, с. 242); багна, позосталі від нільської поводі (2, с. 242); полуднева змора давить усіх (2, с. 242); 2) менталітет, релігійні святині й предмети культу: велетенські постаті богів (2, с. 242); се хата Ра, оселя Озіріса, / притулок для мандрівниці Ізіди, / колиска Горусу, спочивок Фта (2, с. 244); майстерня Тота, Апісовий хлів, Анубіс, Нейт, Амон домують тута (2, с. 244); Я будував би храми / посвоєму, я б видумував нові/ емблеми для богів (2, с. 245); 3) певну соціально-класову ієрархію: полуднева змора давить усіх- $i$ рабів $i$ 
доглядачів (2, с. 242); накаже перше цар, жсерці присудять, / а потім він будує, щзо звелять (2, с. 245); 4) артефакти, що ідентифікують епоху та етнос: А знаєш, я б ховав у пірамідах, / скажу тобі по правді, не ияарів, / а всіх, щзо добрії діла робили (2, с. 246); Я б, може, просто гору обтесав / $i$ в ній попробивав без ліку ходів, / і саркофагів тисячі поставив (2, с. 242); Ото була б новітня піраміда, / якої світ щее не видав! (2, с. 242).

Аналіз показав, що в єгипетському тексті Леся Українка використовує цікавий художній прийом: значення та конотативні смисли слів (просторових реалій) описово передаються за допомогою найменувань богів, що, зрозуміло, привносить у текст відповідний історико-культурний контекст. Так, для характеристики образу храму письменниця використовує низку сполук: хата Pa, оселя Озіріса, притулок для мандрівниці Ізіди, колиска Горусу, спочивок Фта, майстерня Тота, Апісовий хлів.

Друге художнє втілення образу Єзипту - «країна неволі», у якій сонце не живить, а висушує груди, спалює і пригнічує тіло й душу, людина є рабом рабів, а храм стає могилою, - розкрито в індивідуальнохудожньому осмисленні Сонще - Страждання або Смерть: Робітники покидають роботу $i$ вкладаються, здебільшого де хто стояв. <..> падають, як мертві, спати ницьма або горілиць на розпеченім піску, на камінні, на самім краєчку муру (2, с. 242); сонце блищить на спітнілих лобах (2, с. 242); одежа мов палає відблиском гарячого проміння - раби не чують, сплять важким сном, що розпирає ӥм груди спішним, нерівним диханням (2, с. 242); увесь засмічений присохлим пилом (2, с. 242); Голос його хрипкий, змордований, сам він неначе непритомний (2, с. 242); Чи ти на сонці не печешся зрання / до вечора? (2, с. 243). В антитезі, яка полягає у протиставленні двох світів, у синтезі позитивних і негативних конотацій, що їх актуалізовано центральними образами поеми (Сонце, Раб, Храм), розкривається ідейний задум Лесі Українки: подати узагальнений образ поневоленої людини, душевні муки якої завуальовані маревом, присипані розпеченим піском, залиті брудними водами Нілу та прикрашені, як на смертному одрі, лотосами та папірусом.

Традиційне потрактування образу Сонця як предмета культу в Давньому Єгипті знівельовано, адже в авторській інтерпретації його промені завдають страждання людині, спричиняють хвороби або смерть. Це доводить парадигма мікрообразів, «закріплених» за цим мовознаком у тексті драматичної поеми «В дому роботи, в країні неволі»: піски, 
засохлий бруд, багнисті зарослі, спітніле чоло, висохлі груди, знесилене, сухорляве тіло раба, одежа, засмічена присохлим баговінням, шкарубка від засохлого мулу, важкий сон, спішне, нерівне дихання, скипіле серие.

Як філософ і науковець, обізнаний у багатьох сферах еволюційного поступу людства, Леся Українка створює широкий мовний діапазон тлумачення просторових реалій, подає пояснення майже до кожного знакового суспільного явища. У лінгвалізації єгипетського простору вербалізація образу Paбa акумулює у формі риторичних питань параметральні категорії, що позначені здебільшого високим ступенем метафоричності й виводять на передній план імпліцитний модус висловлювання: 1) соціальний коментар тяжкого становища людини в країні неволі: Чи ти на сонџі не печешся зраня / до вечора? (2, с. 242); 2) опис фізичного болю, спричиненого важкою працею: Чи спина не болить? Чи голову не ломить? (2, с. 242); 3) філософське потрактування страждань поневоленої особистості: Tu $з$ кришталю? Ти мідяний? (2, с. 242); Хто в сім клятім краю/ те відає, навіщьо нас мордують? (2, с. 243); Ношу болото на прокляту цеглу / $і$ сам стаю болотом, сам 3 душею! (2, с. 243); Нічого, так і треба, / я мушу знать, що я тут раб рабів (2, с. 243); 4) морально-етичний дискурс у апелюванні до власного $Я$ індивідуума, що визначає духовний потенціал його особистості: $T u$ камінь чи людина? (2, с. 242); 5) історико-світовий підтекст, закладений у формулу «Там, де закінчується раб, починається людина»: Ще не обридло бабратися в фарбах / так, як мені в болоті? (2, с. 242).

Одним із ключових елементів інтелектуальної картини світу авторки є образ Храму. Мовна фактологія засвідчує велику кількість лексикосемантичних одиниць на позначення артефактів, культурний реалій, предметів культу стародавньої єгипетської цивілізації. Леся Українка досягає енциклопедичного рівня в дефініюванні денотата. Так, інтерпретація авторкою синергетики недобудованого святилища, що вимагає крові й людських життів, розкривається в художньо-семантичній площині Храм - Безглузде сховище мериів. Письменниця подає такий контекст: 1) географічно-просторові відомості: площа в околищі Мемфіса; на заході вона переходить у справжню пустелю (2, с. 242); на сході ї̈ оточують зарослі папірусу та лотосу (2, с. 242); 2) розмір і детальний опис зовнішньої форми споруди та іiі частин: величезна будова, ще не скінчена: колонади, подекуди, ще без капітелів, але поставлені по виразному плану, мури з барвистими малюнками, ще пократовані сіткою помічничих ліній, велетенські постаті богів з невикінченими емблемами 
на головах, а декотрі $i$ зовсім ще без голів (2, с. 242); 3) історичний ракурс: багна, позосталі від нільської поводі (2, с. 242); Се чиста нільська повідь (2, с. 242); 4) відомості про те, хто і як будував такі споруди, 3 якого матеріалу вони зроблені: Гурти робітників працюють коло будови: хто робить цеелу, хто носить мул та воду для неї з багнистих зарослів, інші, під наглядом будівничого, вивершують колони, кладуть перші вінці стелі, різьбярі й малярі заходжуються ретельно коло покрас $i$ статуй (2, с. 242); 5) соціальний коментар становища рабів, що возводять на площі величезну будівлю: Ой, спати, спати, спати хоч хвилину, / бо вже не видержу! (2, с. 242); Ну, втомився, / ну, фарба, ну, болото - щуо ж такого?!! (2, с. 242); 6) конотативну складову образу, створену засобами синонімічного ряду просторових номенів і вкладену Лесею Українкою в уста гебрея: Нехай би се був дім, чи там дворець, / чи хоч темниця, клуня, стайня, хлів, / а то-каміння купа величезна, / поставлена стовпами, бовванами, / довготелесими - який в тім глузд? (2, с. 243); 7) міфопоетичний (релігійний) зріз просторового континууму, ускладнений синонімічним рядом просторових номенів: То так неначе царство, в ньому се, / що ми будуємо, є мов дворець, / се хата Ра, оселя Озіріса, / притулок для мандрівниці Ізіди, / колиска Горусу, спочивок Фта, / майстерня Тота, Апісовий хлів, / Анубіс, Нейт, Амон домують тута (2, с. 244).

Дослідження лексичного матеріалу дає підстави стверджувати, що чітко підкреслена дуальність образів драматичної поеми грунтується на антагонізмі лінгвем на позначення вертикального та горизонтального простору. Перший позначений позитивними конотаціями i викликає асоціативні зв'язки із величною архітектонікою землі Сфінкса: величезні колонади, увінчані капітелями, статуї колосальних богів 3 емблемами на головах, стовпи, високі боввани, храми, піраміди, гори; другий - негативними, бо передає високий ступінь культурного регресу, що його спричиняє поклоніння стлілим трунам і богам «з невикінченими емблемами на головах, а декотрі й зовсім ще без голів» (2, с. 242): багна, позосталі від нільської поводі, болотна жижа та мул на одежі, вода, яку не можна пити, тому треба всюди носити з собой глиняні тиковки, розпечена на сонці площа, щэо переходить у пустелю, тремтячі від спеки піски пустелі.

Висновки. Аналіз орієнтального тексту Лесі Українки доводить, що роль письменниці в інтелектуалізації української літературної мови полягає у використанні прийомів і способів мовного моделювання 
дійсності, які дають змогу досягти багаторівневості у структурі художнього образу. Внесок авторки у скарбницю як української, так і світової культури зумовлений глибиною іiі історіософського бачення світу. Відстояні у віках міфологічної місткості характери та образи вона трактувала по-своєму, надавала їм нової глибини, оригінальної філософської наповненості, поетичної свіжості.

Драматичні твори Лесі Українки є не тільки високохудожніми естетичними витворами, але й спонукають читача до інтелектуального пошуку. Глибина мовно-культурної потенції імпліцитних смислів зумовлена естетичними інтенціями авторки поєднати індивідуальноавторську інтерпретацію 3 науковим дискурсом, що дає змогу утворити багатовимірну модель явища або реалії, витлумачити іiі історико-географічний контекст, глибинний філософський зміст, естетичну значущість, функціональні характеристики, зовнішню (або внутрішню) форму. Знакові для літературної мови кінця XIX початку XX століття естетичні здобутки письменниці визначають інтелектуальні вектори еволюції національної словесної культури.

\section{Література}

1. Лисиченко Л. А. Ці невичерпні глибини мови : [монографія] / Л. А. Лисиченко. - X., 2011. - 304, [4] c.

2. Українка Леся. Зібрання творів : у 5-и т. / Леся Українка. - К. : Держлітвидав, $1951-1956 .-$ T. 2. $-1951 .-683$ c.

3. Українка Леся. Зібрання творів : у 12-и т. / Леся Українка. - К. : Наукова думка, 1975 - 1979. - T. 10. - 1978. - 542 c. ; T. 12. - 1979. - 696 c.

4. Черевченко О. М. Ідіостиль Ю. Клена у контексті інтелектуалізаторських мовних традицій українського неокласицизму : автореф. дис. ... канд. філол. наук / О. М. Черевченко. - К., 2001. - 18 с.

Стаття надійшла до редакиії 03.11.2014 p. 